\title{
The Effect of Good Corporate Governance [GCG] on Disclosure of Corporate Social Responsibility [CSR] and Its Implications on Firm Value
}

\author{
Almatius Setya Marsudi*, Gusti Putra Soetanto \\ Atma Jaya Catholic University of Indonesia \\ Jakarta, Indonesia \\ *almatius.marsudi@atmajaya.ac.id
}

\begin{abstract}
The research examines the influence between Good Corporate Governance (GCG) represented by institutional ownership and public ownership on firm value. The study was conducted at 45 manufacturing companies listed on the Indonesia Stock Exchange during the period of 2015 to 2018. The sobel's test method was used in this research to identify the role of corporate social responsibility disclosure (CSRD) as a mediating variable on the influence of GCG on firm value. The results of this study indicate there is a positive influence of institutional ownership on firm value and this study cannot prove CSRD as a mediating variable of GCG and firm value.
\end{abstract}

Keywords-firm value, institutional ownership, public ownership, corporate social responsibility disclosure

\section{INTRODUCTION}

The company's value has become a concern of the company lately. A high company's value will be considered good by potential investors, and vice versa. The increased company's value is marked by high return on investment to shareholders. Several factors that can affect the company's value are profitability, the size of profitability and the company's social responsibility in the form of Corporate Social Responsibility (CSR).

CSR is a concept whereby companies integrate environmental and social concerns in their business interaction and operations with their stakeholders on a voluntary basis. Over the last few decades corporate social responsibility (CSR) has received increasing attention from the corporate world. Many companies that have contributed to economic and technological progress have been criticized due to creating a social problem. The Problems of pollution, waste, resource depletion, safety, workers' rights and status, and the strength of large companies have become the focus of increasing attention and concern [1].

Companies that carry out CSR activities on a regular basis, of course, will make a positive impression on the company in the long term. Heinze [2] explains that profitability is a factor that makes management become free and flexible to express social responsibility to the shareholders. Ross [3] states that profitability shows the ability of companies to generate profits after utilizing a number of resources they have. Bonner and Friedman [4] in their research revealed a positive signal for CSR to the market. Market participants will appreciate the share prices of companies that care about CSR. The greater the company's concern for CSR, the greater the market's appreciation of the company's stock price [5].

Agency problem can be solved by Good Corporate Governance (GCG), where there is behavior to bring personal benefits by disserving the interests of principals. One of the issues in Indonesia in 2012 is BUMI Plc which owned 25\% of BUMI and $75 \%$ of Berau Coal Energy. BUMI Plc was founded by financiers Nat Rothschild and Bakrie which are listed on the London Stock Exchange. In 2012, BUMI Plc received a report of serious financial irregularities in Indonesian operations on the basis of claims made by Whistleblower, large Bumi shareholders suspected of having diverted more than $\$ 1$ billion in assets into Bakrie companies that are controlled by other families by way of transactions with parties related to. This caused Bumi's stock fall $60 \%$ below the IPO price and was suspended from trading in April 2013. The case of a break-in of customer funds by Vice President Citibank amounted to forty billion rupiahs in 2011. The case of a break-in deposit funds of PT. Elnusa Tbk and Batubara Regency Government by Bank Mega disbursed with falsification of signatures involving parties in Bank Mega in 2011 [6].

Although this phenomenon of social responsibility disclosure has emerged for more than two decades, study on the practice of CSRD seems to be centered in the United States, United Kingdom, and Australia [7]. Only a few researches have been conducted in other countries such as Canada, Japan, Malaysia, Germany, New Zealand, Indonesia and Singapore. Various studies related to the disclosure of CSR show that thereis diversity of results. 


\section{LITERATURE REVIEW}

\section{A. Signaling Theory}

This signaling theory states that the company's stock price will change when changes in dividend payments occur. With the increase in the distribution of dividends provides information [a sign] for investors that the company in the future has good prospects. Furthermore Akerlof [8] bases on economic theory that asymmetric information is one of the causes of market failure where due to incomplete information between the two parties, usually if the market is between the seller and the buyer does not have the same information, between the manager [issuer $=$ seller] and investor [buyer] also has asymmetrical information and this will cause one of the parties to be harmed.

\section{B. Value of the Firm}

Firm value is the investor's perception of company achievements related to stock prices. High stock prices make the firm value increase. Salvatore [9] revealed that the firm value is very significant for a company, because increasing the firm value will also increase the prosperity of shareholders [10].

\section{Corporate Social Responsibility [CSR]}

CSR disclosure disclosure is how companies communicate the environmental, social and economic impacts of the organization's activities on society as a whole. Johnson and Johnson [11] revealed that companies must be able to manage their business operations by producing products that are positively oriented to society and the environment. CSR is also a social responsibility that aims to increase the commercial value of the company by taking into account the ethical values and environmental quality of the community, which are based on 3-P, namely economic, ecological and social.

\section{Corporate Governance [CG]}

Corporate governance relates to how investors believe that managers will benefit them, believe that managers will not steal or embezzle or invest in unprofitable projects with regard to funds invested by investors, and with regard to how investors control all the managers [12].

Dharmapala and Khanna [13] revealed that CG investors would tend to avoid companies that have poor CG implementation. The application of GCG can be reflected in the value of the companies concerned. An alternative explanation for the relationship between $\mathrm{CG}$ practices and company's value is signaling theory.

\section{E. The Effect of Institutional Share Ownership on CSR}

A high level of institutional ownership will lead to greater oversight efforts by institutional investors so that it can obstruct managers' opportunistic behavior and improve the quality of investment decisions in social responsibility, so that with greater institutional ownership in a company, then the company tends to make wider disclosures regarding the implementation of CSR disclosures.

\section{F. The Effect of Public Stock Ownership on CSR}

The greater of public shares ownership, the higher of public interest will become the company's responsibility. The public itself is an individual or institution that has a share ownership of fewer than $5 \%$ that is outside management and does not have a special relationship with the company [14].

\section{G. Effect of CSR on Firm Value [Tobin's Q]}

Stakeholder theory states that the sustainability and success of an organization depends on the ability of the organization to be able to meet economic and non-economic aspects, by satisfying the interests of stakeholders [15]. To be able to fulfill economic and non-economic aspects, it is realized in CSR activities. If the share price rises, the company's value in the eyes of investors will also increase [16].

\section{METHODS}

Sample Selection in this study used purposive sampling method. Data is taken from manufacturing companies that go public in Indonesia which are listed on the IDX. The sample was taken from the population of manufacturing companies that listed on the IDX. Data collection develop with the following criteria: (1) Go public or be listed on IDX for three years in a row with the period 2015 - 2018. (2) Publish annual reports for three consecutive years for the 2015 - 2018 period.

\section{A. Definition of Operational Variable}

Measurement of CSR variables uses content analysis that measures the CSR index (CSRI) variety. Institutional stock ownership is the ownership of stock owned by institutional investors. Institutional investors include banks, pension funds, insurance companies, limited liability companies and other financial institutions. Institutional ownership is measured by the amount of share ownership by institutional investors compared to the total shares of the company. The company's value in this study is proxied by using Tobin's q, the reason is that this ratio is a valuable concept for measuring the prosperity of the owner, because it proves financial markets estimates of the return on each unit of money for incremental investment.

\section{B. Analysis Method}

The model to test the hypotheses in this study uses a panel data regression model (a combination of time series and cross section) using the help of the computer statistics application program SPSS. Heteroscedasticity Test is also performed which usually occurs in cross section error data, where panel data is closer to the cross section data characteristics than time series. F test is used to determine the existence or the absence of the simultaneously influence between the independent variables with the dependent variable. To find out the influence of independent variable (IO, PO, and CSRD) individually on the variation of CSRD we used t-test. 


\section{RESULTS AND DISCUSSION}

\section{A. Descriptive Statistics}

From the data, we can be seen data distribution of 45 manufacturing companies listed on the stock exchange since 2015-2018. Table 1 gives descriptive statistics on all variables related to $\mathrm{FV}$ :

TABLE I. DESCRIPTIVE STATISTIC

\begin{tabular}{|l|c|l|l|l|l|}
\hline & N & Minimum & Maximum & \multicolumn{1}{|c|}{ Mean } & Std. Dev \\
\hline IO & 135 & 10,13 & 110,20 & 74,4541 & 21,53510 \\
\hline PO & 135 & 25,21 & 150,45 & 67,2321 & 25,45621 \\
\hline CSRD & 135 & 18,15861 & 53,48191 & 34,1055021 & 7,46357879 \\
\hline FV & 135 &, 147366 & 1,414749 & 1,10753712 &, 229442960 \\
\hline
\end{tabular}

1) First model: The coefficient of determination. Table 2 gives coefficient of determination of the first model:

TABLE II. DETERMINATION COEFFICIENT

\begin{tabular}{|l|c|c|c|c|}
\hline Model1 & $\mathbf{R}$ & $\mathbf{R}^{\mathbf{2}}$ & Adjusted R & $\begin{array}{c}\text { Std. The error } \\
\text { Of the Estimate }\end{array}$ \\
\hline 1 &, 452 &, 204 &, 190 & 3,11762 \\
\hline
\end{tabular}

R2 value of 0.204 means that $20.4 \%$ of CSRD variables are explained by two independent variables.

$F$ test of the first model. The influence of the independent variables on CSRD together can be seen in table 3 .

TABLE III. ANALYSIS OF VARIANCE

\begin{tabular}{|c|l|l|l|l|l|c|}
\hline \multicolumn{2}{|c|}{ Model 1 } & $\begin{array}{c}\text { Sum of } \\
\text { Square }\end{array}$ & df & $\begin{array}{c}\text { Mean } \\
\text { Square }\end{array}$ & F & Sig. \\
\hline 1 & Regression & 5412.452 & 2 & 1299.343 & 34,409 & 0,000 \\
& Residual & 5116.587 & 133 & 36,725 & & \\
& Total & 10529.039 & 135 & & & \\
\hline
\end{tabular}

The results of the $\mathrm{F}$ test indicate a significant effect can thus be concluded passing the goodness of fit test. Partial test results (t test) showed that IO has a significant effect on CSRD with a value of sig, 0,000 .

$t$ test of the first model. The result of partial test ( $t$-test) between IO, and PO on CSRD on the table 4.

TABLE IV. PARTIAL REGRESSION CALCULATION

\begin{tabular}{|c|l|l|l|l|l|l|}
\hline \multirow{2}{*}{ Model 1 } & \multicolumn{2}{|c|}{$\begin{array}{c}\text { Unstandardized } \\
\text { Coeff. }\end{array}$} & $\begin{array}{c}\text { Standardized } \\
\text { Coeff. }\end{array}$ & \multirow{2}{*}{ T } & \multirow{2}{*}{ Sig. } \\
\cline { 3 - 5 } & \multicolumn{1}{|c|}{ B } & Std. error & Beta & & \\
\hline \multirow{2}{*}{1} & {$[$ Constant] } & $-43,534$ & 8,762 & & & \\
& IO1 &,- 036 & 0,27 &,- 079 & $-1,326$ &, 167 \\
& PO1 &, 459 &, 245 &, 164 & 2,451 &, 032 \\
\hline
\end{tabular}

The statistical equation of the simple linear regression:

$C S R D=-43,534+-0,036 \mathrm{IO} 1+0,459 \mathrm{PO} 1$
2) Second model: The coefficient of determination. In the table 5 we can know noefficient of determination of the first model:

TABLE V. DETERMINATION COEFFICIENT

\begin{tabular}{|l|c|l|l|l|}
\hline \multicolumn{2}{|c|}{ Model 1 R } & Rdjusted R $^{2}$ & $\begin{array}{c}\text { Std. The error of the } \\
\text { Estimate }\end{array}$ \\
\hline 1 &, 572 &, 327 &, 215 & 3,6562 \\
\hline
\end{tabular}

R2 value of 0,327 indicates $32.7 \%$ of Firm Value (FV) variables are explained by tree independent variables.

F test of the second model. Based on the testing that has been done, we can know the influence of the independent variables on CSRD together from table 6.

TABLE VI. ANOVA

\begin{tabular}{|c|l|l|l|l|l|c|}
\hline \multicolumn{2}{|c|}{ Model 2 } & $\begin{array}{c}\text { Sum of } \\
\text { Square }\end{array}$ & df & $\begin{array}{c}\text { Mean } \\
\text { Square }\end{array}$ & F & Sig. \\
\hline 1 & Regression & 3,452 & 2 & 0,776 & 50,209 & 0,000 \\
& Residual & 2,158 & 133 & 0,025 & & \\
& Total & 5.610 & 135 & & & \\
\hline
\end{tabular}

The results of the F test indicate a significant effect can thus be concluded passing the goodness of fit test. Partial test results ( $\mathrm{t}$ test) showed that CSRD has a significant effect on FV with a value of sig, 0,000 .

$t$ test of the first model. The result of partial test (t-test) between independent variable (IO, PO, and CSRD) on FV can be seen in Table 7 .

TABLE VII. PARTIAL REGRESSION

\begin{tabular}{|c|l|l|l|l|l|l|}
\hline \multirow{2}{*}{ Model 2 } & \multicolumn{2}{|c|}{$\begin{array}{c}\text { Unstandardized } \\
\text { Coeff. }\end{array}$} & $\begin{array}{c}\text { Standardized } \\
\text { Coeff. }\end{array}$ & \multirow{2}{*}{ t } & \multirow{2}{*}{ Sig. } \\
\cline { 3 - 5 } & B & Std. error & Beta & & \\
\hline \multirow{2}{*}{1} & {$[$ Constant] } &,- 056 &, 328 & & & \\
& IO2 &, 000 & 0,03 &, 027 &, 534 &, 611 \\
& PO2 &, 013 &, 005 &, 120 & 1,588 &, 032 \\
& CSRD &, 001 & 0,01 &, 019 &, 462 &, 723 \\
\hline
\end{tabular}

The statistical equation of the simple linear regression:

$\mathrm{FV}=-, 056+-0,, 000 \mathrm{IO} 2+0,013 \mathrm{PO} 2+0,001 \mathrm{CSRD}$

\section{B. Mediation Variable}

CSRD was used as a mediator variable. By using mediation testing we can find out how strong the CSRD variables mediate between independent factors to dependent factors.

TABLE VIII. MEDIATION TEST

\begin{tabular}{|l|l|l|l|}
\hline Variables & \multicolumn{1}{|c|}{ P2p3 } & Sp2p3 & t-count \\
\hline IO & 0,00027 & 0,00018 & 1,01452 \\
\hline PO & 0,00284 & 0,00286 & 1,54417 \\
\hline
\end{tabular}

Table 8 can reveal that $t$ count value is 1.96 , Because 1,96> $\mathrm{p}$ value 0,05 the result means that there is no mediator variable of the relationship between IO, PO and CSRD. 


\section{CONCLUSION}

The conclusion of this research paper: 1) The result of $t$ test-model 1 reveal that the variable of Public Ownership model 1 has significant effect on CSRD, 2) On t test-model 2 find that only the variable of Institution Ownership model 1 has significant effect on Firm Value, and 3) Mediation test results indicate that CSRD is not a mediating variable on the influence between IO and PO on FV. There are limitations in this study because of the low $r^{2}$ value, this is due to the possibility that there are other variables that influence.

\section{REFERENCES}

[1] R. Gray, M. Javad, D.M. Power, and S.C. Donald, "Social And Environmental Disclosure, And Corporate Characteristic: A Research Note And Extension,” J. Bus. Financ. Account., vol. 28, no. 3-4, pp. 327-356, 2001.

[2] D.C. Heinze, "Financial correlates of a social involvement measure," Akron Bus. Econ. Rev., vol. 7, no. 1, pp. 48-51, 1976.

[3] R.W. Jeff, Corporate Finance, 9th ed. Irwin, McGraw-H, 2012.

[4] Julia Bonner and A. Friedman, "Corporate Social Responsibility: Who's Responsible? Finding an Organizational Home for an Increasingly Critical Function," J. NewYork Univ., pp. 1-10, 2016.

[5] A. Lako, Dekonstruksi CSR dan Reformasi Paradigma Bisnis dan Akuntansi. Jakarta: Erlangga, 2011.

[6] K. Onasis and R. Robin, "Pengaruh tata kelola perusahaan terhadap nilai perusahaan pada perusahaan sektor keuangan yang terdaftar di BEI," Bina Ekon., vol. 20, no. 1, pp. 1-22, 2016.
[7] D. Hackston, Marcus J., and Milne, "Some Determinants Of Social And Environmental Disclosures In New Zaeland Companies," Accounting, Audit. Account. J., vol. 9, no. 1, pp. 77-108, 1996.

[8] G.A. Akerlof, "The Market for Lemons: Quality Uncertainty and the Market Mechanism,” Q. J. Econ., vol. 84, pp. 488-500, 1970.

[9] D. Salvatore, Ekonomi Manajerial dalam Perekonomian Global. Jakarta: Salemba Empat, 2011.

[10] E. Soliha and Taswan, "Pengaruh Kebijakan Hutang Terhadap Nilai Perusahaan Serta Beberapa Faktor Yang Mempengaruhinya," J. Bisnis dan Ekon., vol. 9, no. 2, pp. 149-163, 2002.

[11] D.W. Johnson, R.T. Johnson, and E.J. Johnson-Holubec, Cooperation in the Classroom. Bandung: Alfabeta, 2003.

[12] A. Shleifer and R.W. Vishny, "A survey of corporate governance," J. Finance, vol. 52, no. 2, 1997.

[13] D. Dharmapala and V. Khanna, "Corporate Governance, Enforcement, and Firm Value: Evidence from India," in 3rd Annual Conference on Empirical Legal Studies Papers, 2011, p. 43.

[14] V.R. Furi and Saifudin, "Faktor-faktor yang Mempengaruhi Struktur Modal (Studi Empiris pada Perusahaan Manufaktur yang Terdaftar di BEI Tahun 2009-2010)," Juraksi, vol. 1, no. 2, 2012.

[15] J. Pirsch, S. Gupta, and S.L. Grau, "A framework for understanding corporate social responsibility programs as a continuum: An exploratory study," J. Bus. ethics, vol. 70, no. 2, pp. 125-140, 2007.

[16] Rosiana and G. Ayu, "Pengaruh Pengungkapan CSR pada Nilai Perusahaan dengan Profitabilitas sebagai Variabel Pemoderasi," e-Jurnal Akunt. Univ. Udayana, vol. 5, no. 3, pp. 723-738, 2013. 